\title{
A PRIMEIRA TRADUÇÃO PORTUGUESA DA DESCRIÇÃO DAS ÍNDIAS ORIENTAIS POR LINSCHOTEN (1596)
}

O Itinerário, Viagem ou Navegação de Jan Huygen van Linschoten para as Índias Orientais ou Portuguesas ${ }^{2}$ é, sem dúvida, um dos textos que tem mais importância para o conhecimento do conjunto de países que foram tocados pelo ramo principal da expansão portuguesa ao longo do século XVI. Publicado em holandês em 1596, o livro foi logo traduzido em inglês, alemão e latim, e, pouco depois (1610), em francês. Mas nunca tinha sido, até hoje, traduzido nem em castelhano nem em português.

O facto pode parecer paradoxal mas deve explicar-se, no contexto fervilhante da época, pelo enorme interesse que o livro e os seus anexos (em particular uma compilação dos roteiros de navegação dos Portugueses no Oriente) despertaram entre os povos marítimos do Norte da Europa, que estavam tentando organizar a própria expansão ultramarina, na altura em que o enorme império ibérico conhecia os primeiros revezes. Os responsáveis espanhóis e portugueses devem ter considerado o livro de Linschoten como uma desastrosa traição, que não convinha divulgar mais na própria esfera de influência.

Mas se esta reacção de ignorância foi compreensível na passagem do século XVI para o seguinte, muito mais estranho e lamentável, do ponto de vista científico, se torna a persistência, durante quatro séculos, do silêncio feito em Portugal à volta desta obra fundamental. Apenas se divulgaram e se conhecem, usualmente, algumas das excelentes gravuras que Linschoten desenhou e incorporou no seu relato. Ainda que muitas vezes reproduzidas, aquelas perdem grande parte do seu significado quando separadas do texto que ilustram.

Linschoten era um jovem holandês que, com 16 anos, foi procurar vida em Sevilha, passando a seguir para Lisboa. Em 1583 conseguiu embarcar para a Índia como secretário de D. Vicente da Fonseca, que Filipe II acabava de nomear arce-

1 Professora Universitária Jubilada. Investigadora do Centro de Estudos Geográficos. Universidade de Lisboa.

2 POS, Arie; LOUREIRO, Rui (eds.), Itinerário, Viagem ou Navegação de Jan Huygen van Linschoten para as Índias Orientais ou Portuguesas, C.N.C.D.P., "Outras Margens”, Lisboa, 1997, 416 p., 39 gravuras. 
bispo de Goa. Estanciou nesta cidade até finais de 1588, voltando então para a Europa, via Santa Helena e Açores, tendo permanecido na Terceira durante ano e meio, para tomar conta da carga de um navio naufragado. Chegou a Enkhuisen em 1592, dedicando-se então à publicação dos conhecimentos adquiridos ao longo da sua grande viagem, e participando igualmente nas malogradas tentativas que fizeram os holandeses para descobrir a "passagem do norte" até ao Oriente.

Transmitiu ao público uma relação muito completa de tudo que conseguiu saber tanto sobre os países que conheceu directamente como sobre o enquadramento geográfico e económico no qual se inseriam. A informação é densa, equilibrada, e parece muito segura. O ponto de vista de um estrangeiro, ainda que muito bem integrado na sociedade portuguesa, tem um especial interesse. Escreveu num estilo simples e directo, vivo e atraente, e soube juntar ao texto uma ilustração abundante e de qualidade, que constitui um dos melhores testemunhos sobre a sociedade cosmopolita que animava então as ruas de Goa. Magnificamente reproduzidas na presente edição, as gravuras, executadas na Holanda, são baseadas nos próprios desenhos do autor, o que lhes dá um valor ímpar, a despeito dos pequenos desvios que o gravador pode ter introduzido. Linschoten soube também fazer obra de cartógrafo, tendo incorporado no seu Itinerário preciosas vistas, desenhadas por ele, das ilhas de Moçambique, Santa Helena e Ascenção, e das cidades de Goa e Angra; juntou também três cartas náuticas de compilação, baseadas em originais portugueses, que se estendem do Sul da África até ao Extremo Oriente.

A presente tradução resulta da colaboração de Arie Pos, que ensina Literatura Neerlandesa na Universidade de Coimbra, com Luís Manuel Loureiro, doutor em História da Expansão Portuguesa pela Universidade de Lisboa. A publicação está inserida na colecção Outras Margens, que a Comissão Nacional para as Comemorações dos Descobrimentos Portugueses começou a divulgar em 1997. Esta colecção recomenda-se pela sua excelente apresentação, simples, elegante e racional, em boa parte devida ao cuidado posto na organização dos livros pela Dr. ${ }^{a}$ Clara Boléo, que coordena a sua preparação. Para os geógrafos tem especial interesse, de entre as obras já divulgadas e além do presente livro, a 1. ${ }^{a}$ edição do Roteiro das Cousas do Achem (Norte de Samatra) de D. João Riveiro Gaio e a 2. ${ }^{\mathrm{a}}$ edição dos Tratados da Terra e Gente do Brasil de Fernão Cardim, dois documentos corográficos de notável conteúdo, ambos mais ou menos contemporâneos do depoimento de Linschoten; mais, naturalmente, a excelente reedição de A Ilha do Fogo e as suas Erupções, de Orlando Ribeiro (1954). 